\title{
The Shock of the Risky(Qué) Female: Femininity and the trauma of the Great War Era in the dancing of Maud Allan and Anna Pavlova ${ }^{1}$
}

\author{
Victoria Thoms ${ }^{2}$ \\ Centre for Dance Research/C-DaRE, Coventry University, Coventry/UK \\ E-mail: ac1420@coventry.ac.uk
}

\begin{abstract}
What role did the figure of the dancing female play in negotiating cultural anxieties in the Great War era? I explore this question by looking at the female performer Maud Allan who was famous for her danced interpretations of Salomé in pre-War London and cause of a sensational libel suit in 1918 bring together deviant female sexuality and wartime espionage. I juxtapose Allan with ballerina Anna Pavlova, a contemporary, and role model par excellence for proper femininity. These two examples offer a rich comparison from which to discuss how dancing and femininity was the grounds for inciting and palliating the profound cultural trauma of the Great War era.
\end{abstract}

Keywords

Dance. Femininity. Cultural Trauma. Great War Era.
Qual foi o papel da figura da dançarina feminina na negociação das ansiedades culturais na era da Primeira Guerra Mundial? Eu exploro essa questão analisando a performer Maud Allan, famosa por suas interpretações dançadas de Salomé na Londres do pré-guerra e a causa de um extraordinário processo por difamação em 1918, que une sexualidade feminina desviante e espionagem em tempos de guerra. Justaponho Allan com a bailarina Anna Pavlova, sua contemporânea, modelo por excelência de uma feminilidade adequada. Esses dois exemplos oferecem uma rica comparação a partir da qual podemos discutir como a dança e a feminilidade foram as bases para incitar e atenuar o profundo trauma cultural da era da Primeira Guerra Mundial.

Palavras-chave

Dança. Feminilidade. Trauma Cultural.

Era da Primeira Guerra Mundial. 
Figure 1 - Image cropped from "Slaying Militarism with the Pen" The Sketch, January 6, 1915.

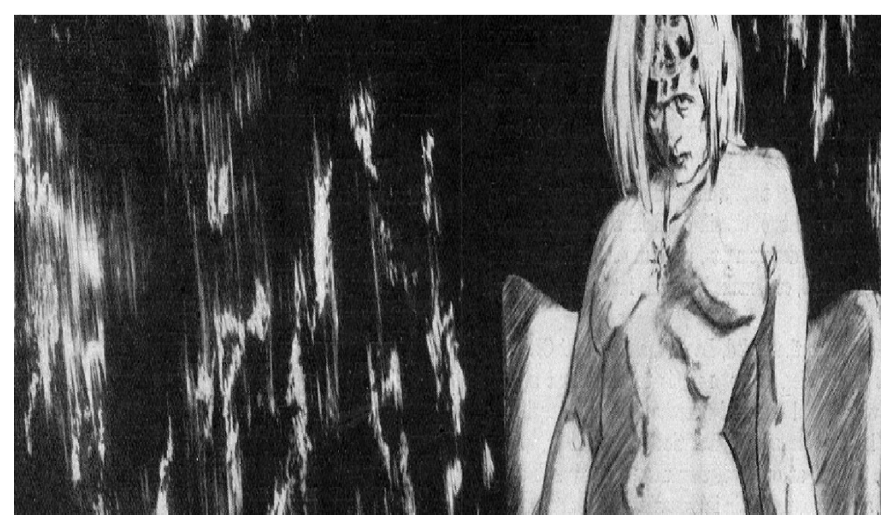

Source: @ Illustrated London News Ltd/Mary Evans.

All Rights Reserved.

What role did the figure of the dancing female play in negotiating the cultural anxieties of the First World War era? How might these anxieties be related to the era's troubling of traditional and hegemonic ideas about femininity and masculinity? Finally, how might we understand the trauma endemic to the early twentieth century as symptomatic of this gender trouble? In this essay, I open a discussion of cultural trauma as stemming from anxieties around femininity and identity played out against the

1 I am grateful for the opportunity to present early thinking on this topic at the Research Café organized by Juliet Simpson for the Faculty of Arts and Humanities, Coventry University in March 2016 as well as at Pack Up Your Troubles: Performance Cultures in the First World War, a conference hosted by Kent University in April 2015 as part of their AHRC co-funded Gateways to the First World War public engagement project. I would also like to thank Luci Gosling at the Mary Evans Picture Library for her knowledge and guidance in sourcing the images presented. The staff at both the British Library Newspaper Collection and the Victoria and Albert Theatre and Performance collections at Blythe House were also enormously helpful.

2 Victoria Thoms is a dance philosopher interested in practical and theoretical debates that bring together performance, trauma, and gender studies. She is author of a monograph on Martha Graham (2013) and is member of the executive committee of The Society for Dance Research in the UK. backdrop of the Great War and deeply influenced by the social upheaval and devastating loss of life due to the conflict. I explore these anxieties by looking at the female performer Maud Allan who was famous for her erotically charged danced interpretation of Oscar Wilde's infamous character Salome in preWar London and who was the cause of a sensational libel suit in 1918 that brought together deviant female sexuality and wartime espionage. To theorise the effects of Allan's supposed aberrance, I juxtapose her with ballerina Anna Pavlova, whose faultless image and prolific international touring made her both respected and a role model for proper femininity. Her untimely death in 1931 from pneumonia provoked an unprecedented international expression of mourning. These two examples offer a rich comparison from which to discuss how gender and female identity, in particular, can be read as the root of a significant cultural crisis. A cultural crisis linked to the traumas embedded within the socio-cultural cataclysms of the early twentieth century including not only the Great War itself but also things like the Russian Revolution and the Suffragette movement. Through these examples, I argue that gender is a formidable form of what I call a 'constellation of trauma' that left an indelible mark on those that survived the Great War conflagration.

Allan and Pavlova are not often directly compared or even considered peers. Allan's legacy is a footnote in Edwardian history (MCDEARMON, 1978). Pavlova, on the other hand, has experienced a sustained cult status as one of the greatest ballerinas of all time (FISHER, 2012). Allan and Pavlova had similar beginnings to their London dance careers. They both had their London premieres at the Palace Theatre, a variety theatre, within two years of each other. Allan premiered there in 1908, Pavlova in 1910. Pavlova, in fact, chose the Palace because of its association with Allan (MONEY, 1982) and was greatly influenced by the style epitomised by Allan in putting together her early programmes (PRITCHARD, 2013). It is quite likely that Allan would also have paid attention to Pavlova's performances. This link sets up a singular and important convergence for two careers that later 
radically diverged, and perhaps this connection has not been given enough emphasis. Indeed, it is the bifurcating historical trajectories of Allan and Pavlova from this point of origin and how the trajectories mediated differing socio-cultural responses to the events of early twentieth century London that make this initial proximity both surprising and uncanny. This point of origin offers a temporally extended discussion about the cultural trauma associated with anxieties about nation and empire through changing notions of proper femininity in popular British concert dance.

To set the stage, I introduce Allan and Pavlova and suggest that both mediated particular sociocultural responses to the events of this era. This was not only in how their female identity was understood and the kinds of effects this positioning manifested but how their dancing played a central role in this process. I also therefore give particular attention to their signature works that became synonymous with their public identities: for Allan, this was her notorious work The Vision of Salome (1906); and for Pavlova, the elegiac The Dying Swan (1905). In looking at these works, I focus particular attention on the context surrounding their premieres in London in 1908 and 1910 respectively. I then explore what I consider to be summative events in the public history of these women - Allan's 1918 libel case and Pavlova's death 23 years later in 1931 - and how these events illustrate the influence that gender brings to bear on cultural trauma. These events, spread across more than two decades of enormous change, are brought together in my thinking in how they incited a sometimes global, social and collective response about the character of woman. The dancing and public persona of these two iconic female dancers generated vast public interest and led to the congregating of people - from the sold-out months-long runs of the Palace Theatre to the mass impromptu gatherings of people in public spaces. Their dance outstripped the boundaries of their subculture and infused larger populations, serving as powerful mediators of social desires and anxieties ${ }^{3}$.This effect is evident in how Allan's dancing came to be understood in the last months of First World War London as a deviant, socially destructive and even evil (PATTERSON, 2017) form of female identity and how, in turn, Pavlova's dancing gradually assuaged the wounds to hegemonic masculinity wrought by the era through its return to deferential and containable proper femininity.

\section{The Female Leads}

The pre-First World War London that Allan and Pavlova encountered, approximately within a year of each other, was one of the wealthiest cosmopolitan capitals in the world. The British Empire was at the height of its imperial power and London, as its capital, was a meeting point for multiple transnational identities. With 7.25 million people by 1914, Greater London had the largest population density of any urban centre in the western world at that time (GOEBEL; WHITE, 2016) ${ }^{4}$. This size and influence, coupled with the effects of nineteenth century industrialisation saw the emergence of a greater heterogeneous strata of classes, especially the unprecedented rise of civil and administrative middle to upper middle classes. This was a potent variegated situation that loosened social and geographically-bound restrictions around acceptable identities and challenged, especially for women, the contained and silent modesty of Victorian ideas of female corporality (WALKOWITZ, 2013, p. 339). The change was aided by a burgeoning print culture that served to promote new ideas about class, nation, sexuality and gender (KELLY, 2004). Dance exhibitions given by solo females were made

3 To gauge this border crossing, I have looked at the frequency and content of a variety of print publication specific to a British context, considering not only how the events were reported but also in what kinds of publication. This ranged from the dance-focused the Dancing Times, a monthly publication; to weekly Society publications including, The Sketch, The Tatlerand The Illustrated London News; to finally, the national dailies, both broadsheets and tabloids, including, The Telegraph, the Daily Mail, The Observer, The Manchester Guardian, the Daily Mirror and The Times.

4 www.tandfonline.com/doi/pdf/10.1080/03058034.2016. 1216758. 
acceptable and popular by American imports such as Isadora Duncan and came to be seen as a form of national culture (WALKOWITZ, 2003, p. 338, 342). This pre-War environment was ripe for, and celebrated in, the ambivalent pleasure-seeking Salomania that Allan's dancing came to represent - a constellation of feeling that the first programmes given in London by Pavlova reinforced with the inclusion of primitivist short-works (or divertissement) such as Bacchanaleand Valse Caprice (PRITCHARD, 2013, p. 63). The Salome-charged cultural climate of preWar London offered a form of sanctioned femininity that was urbane, razor-edged, pleasure-seeking and permissive, something quite different to the anti-Salome frenzy during the closing months of the war.

Ullah Maud Durrant, otherwise known as Maud Allan, arrived into this progressive environment in the late weeks of February 1908. She was born in Toronto in 1873 but later moved to San Francisco with her family. Her main sustained mode of study and ability was in music. During her early years in the United States, she showed promise as a pianist, studying at a local conservatoire in San Francisco which eventually progressed to a move to Berlin in 1895 to enhance her abilities and pursue the promise of a professional career (CHERNIAVSKY, 1991).

Losing interest in music, she started to experiment with free movement/Greek revivalist dancing made popular by Isadora Duncan in 1899 and made her dancing debut in Vienna in 1903. After middling success, she was asked to perform at a private event held for Edward VII in the resort of Marienbad in early 1908 where she performed a selection of both her Greek natural dancing and her Orientalist work The Vision of Salome. Edward was greatly impressed by her work and this led to an introduction to Alfred Butt, one of London's leading impresarios and the manager of the Palace Theatre, where she was booked for an initial two week run. From there she became an overnight sensation and maintained that success for the next two years (WALKOWITZ, 2003). This fame extended past the stage into the environs of Upper London society and politics.
While the majority of Allan's dancing was in the style of Greek inspired natural movement and performed to recognised composers including Chopin and Mendelsohn ${ }^{5}$, without a doubt what made her fame and what she is remembered for was her danced interpretation of Salome ${ }^{6}$. This was based on the eponymous character made famous by Oscar Wilde's play in which Salome agrees to dance for King Herod, her uncle, if he gives her the head of John the Baptist. Calling her versionThe Vision of Salome, Allan performed with a life-like replica of John the Baptist's severed head, an experience that the Financial Times described as, "magnificent in its sinuous beauty, its climax is yet so gruesome as to make the flesh creep and the blood run cold.

5 Reviews of her work from her debut in March 1908 through to final notices of her first run in London in late 1909 can be found across a swathe of popular press. See P.G.K., "Canadian Who Will Stir London," Daily Mail, 7 March 1908, UKpressonline; "The Poetry of Motion," Financial Times, 7 March 1908, Financial Times Historical Archive; "The Drama," London Daily News, 7 March 1908, The British Newspaper Archive; and "Miss Maud Allan, the new dancer at the Palace Theatre," The Tatler Sporting and Country House Supplement, 11 March 1908. These of course mention the Vision of Salome but also indicate that her programme featured much Greek-inspired natural movement which was often enthusiastically reviewed.

6 It is difficult to find any commentary on Allan that does not in some way also mentionThe Vision of Salome. See for instance, Farfan (2015), "Masculine Women"; Bland (2013), Modern Women; Medd (2012), Lesbian Scandal; and Koritz (1995), Gendering Bodies/Performing Art. There are also several examples of The Vision of Salome's influence on its Edwardian audience including the Salome parody "Sal Oh-My" that opened at the Alhambra soon after Allan's debut and the rather startling reproduction of the Allan's Salome character by a group of female children employed by another parody done by the Edwardian musical comedienne Phyllis Dare. See "Dressed in a Chic Ventilation: Miniature Salomes," The Sketch Supplement, 24 June 1908; and "The Vison of Salome' Parodied: 'Sal-oh-my'," The Sketch, 29 April 1908. 
Figure 2 - Maud Allan with the Head of John the Baptist.

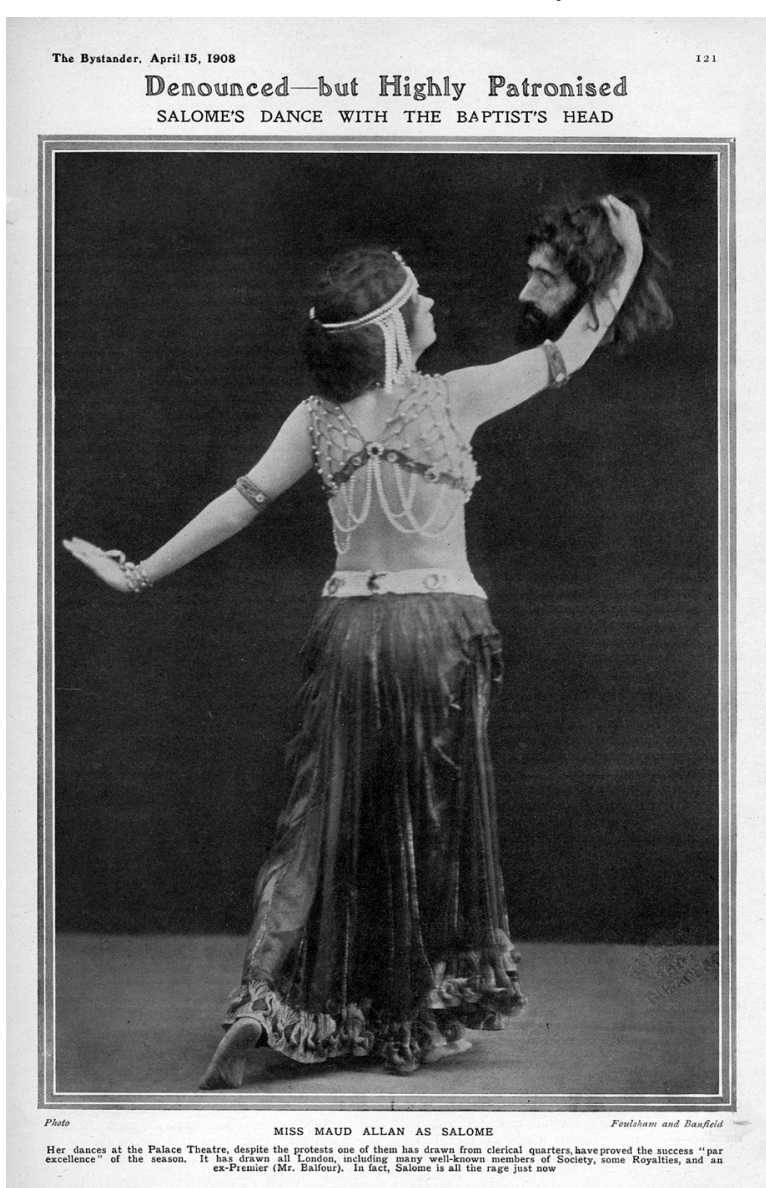

Source: ( Illustrated London News Ltd/Mary Evans. All Rights Reserved.

What is also noticeable in Allan's version is her Salome costume which featured a mobile see-through and ornate beaded top of white pearls and black beads made to look surprisingly like breasts. The costume was finished with a long diaphanous black skirt with diamond-like beads encrusting its hem (see Figure 2).

What Allan's movement in these works actually was is difficult to determine. While Pavlova leaves behind a film, there is no existing moving example of Allan's dancing (WEIGARD, 1985) ${ }^{7}$.Nevertheless, while partly caricature, the drawing by H.M. Brock below taken from TheGraphicmagazine of-

7 Weigard (1985), "The Rugmaker's Daughter," who suggests that the silent film Allan made in 1915 called Rugmaker's Daughter included examples of both her Greek dancing and elements of The Vision of Salome; this film is now lost. fers someindication of what Allan'smovements might have been bothin her Greek revivalist dances aswell as her interpretation of Salome (see Figure 3).

Figure 3 - Allan dancing at the Palace Theatre.

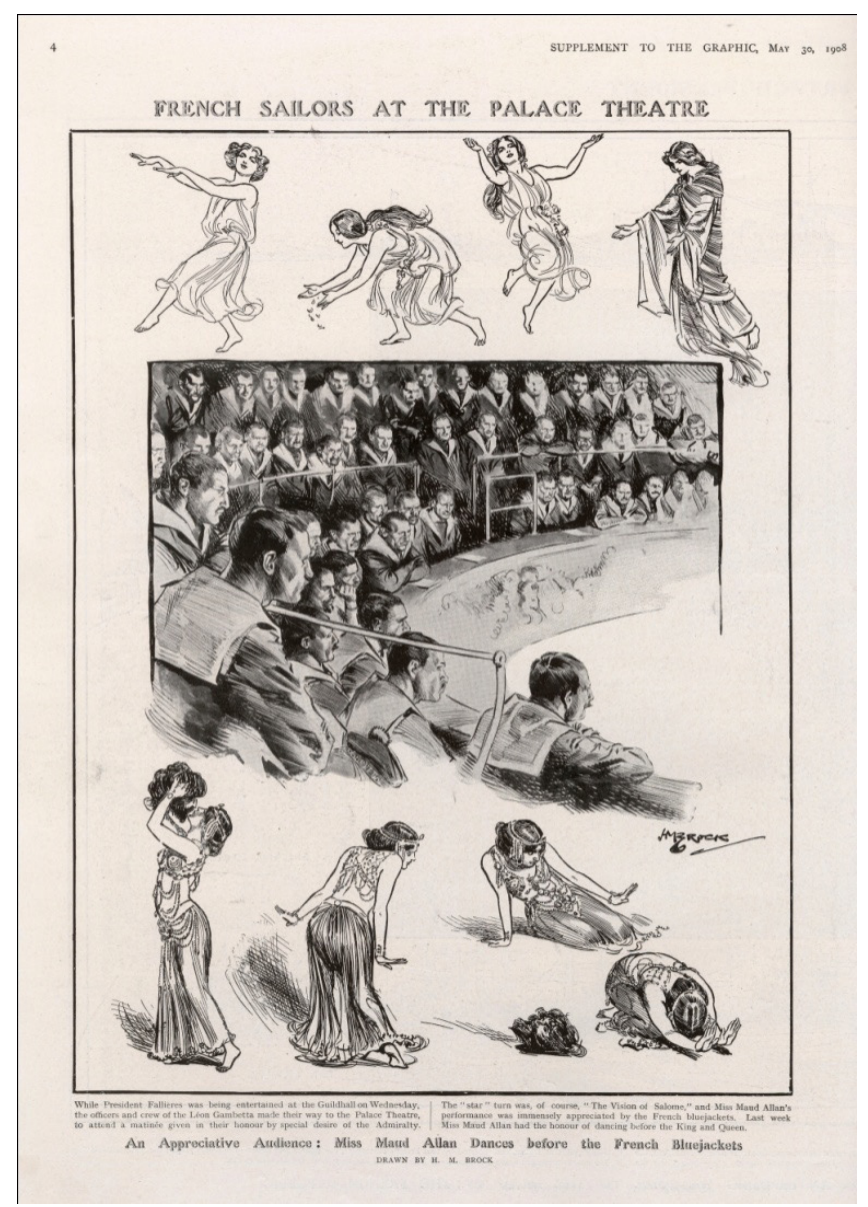

Source: ( Illustrated London News Ltd/Mary Evans.

AllRightsReserved. The ShockoftheRisky(qué).

In considering Allan's movement in these insets, it is not possible get a specific sense of movement dynamics, the sequences of the movements, or Allan's position on the stage. Nevertheless, they do give us a sense of Allan's bodily tension and the flow of movement; how she used levels going down to the floor to lay or kneel; and the thematic intention of the pieces. One can get a feeling for Allan's movement from the way the fabric is drawn and how the body is positioned to indicate transfers of weight. The top inset illustrates her more Greek-inspired dancing that appears to comprise of energetic space-covering movement combinations and the bottom indicates a more 
static place-based study. In all instances, what is evident is the mobility and range of Allan's torso whether it is bending back or curving forward and how this freedom in the torso allows for a greater repertoire of bodily expression in the dance. This can be seen in the arm gestures; and without the restriction of footwear, the tension and position of the feet offer a further dimension to the dancing'sexpressive qualities.

Between her début in 1908 and her final pre-War season at the Palace in 1911, Allan also maintained a significant portfolio of special commissions and private patronage which included by-invitation-only performances of her works in events like the private garden parties of the capital's cultural and political elite (CHERNIAVSKY, 1991). It is through these connections that Allan became close friends with both Margot Asquith and her husband the then Prime Minister, Herbert Henry Asquith. Always vigilant to counterpose the still ambivalent propriety associated with being a solo female performer, especially given the charged eroticism of her onstage Salome, Allan was rigorous in policing information about her personal and private life (MCDEARMON, 1978; WALKOWITZ, 2003). This was doubly important for Allan because of the secret she maintained involving her brother. Theo who was arrested, found guilty and executed in San Francisco for the murder of two women in 1898 (CHERNIAVSKY, 1991). The association to the Asquiths in particular made her an increasingly charged public figure ${ }^{8}$ because of polarised opinions about Asquith's policies in the run up to the First World War and the often perceived unhealthy political influence of his wife Margot. This included rumors about the close intimacy she shared with both husband and wife (BLAND, 2013; MEDD, 2012).

Arriving in London as she did in the height of Edwardian cosmopolitanism, Allan's dancing contributed to a cultural milieu that was emerging from and defying the rigidity of the Victorian era, shifting from the masculine gendering of social space to a one which women could increasingly occupy and actively

8 Popular with the Upper 10, Downing Street, The Sketch Supplement, 24 June 1908. participate in. The context of the Brock image of Allan above with its pointed inclusion of her all-male audience could well have been chosen by The Graphicfor its salacious potential, but Palace audiences were increasingly heterogeneous in character both in terms of class and gender (WALKOWITZ, 2003). Dance increasingly found its place in this milieu as a contributor to shifts in the make-up and consumption of national culture. Allan's popularity in particular, coming as it did at the zenith of Edwardian London, captured this era of permissiveness. Cultural historian Judith Walkowitz gets at what the visceral and fantastical force of Allan's embodied danced performance of the character of Salome might have been for the audiences of the time when she describes Allan as "a solitary, autonomous, unfettered, mobile, weighted and scantily clad female body whose movement delineated emotional interiority, shifting states of consciousness and autoeroticism" (WALKOWITZ, 2003, p. 340).

Indeed, the work's alluring orientalist costuming, and passionate duet with a life-like replica of a severed head, presented through the enfleshed and expressive form of solo 'natural' movement performance exemplified the rapid renegotiation of traditional and acceptable forms of identity that characterised pre-War Edwardian society.

Looking now at Anna Pavlova, there are interesting similarities to Allan. Both were foreign dancing imports. Pavlova was born in $1881^{9}$ (MONEY, 1982)in St Petersburg, about seven years after Allan. While Allan's training was in music, Pavlova trained specifically in dance, graduating from the Maryinsky Theatre School on Theatre Street in 1891 (KERENSKY, 1982).She immediately entered the Imperial Ballet and although her slight build and expressive style positioned her as against type to other female stars such as Mathilde Kschessinska (PRITCHARD, 2013, p. 10)she side-stepped the lower ranks of the corps de ballets and quickly progressed to performing as a featured solo artist. Pavlova began international touring in 1907 and in the spring of 1910 made her

9 There is some ambiguity around her birthday. See Money (1982), Anna Pavlova. 
public London debut at the Palace Theatre, an event that was greatly anticipated and an unprecedented success ${ }^{10}$.She would dance with Diaghilev and her former Russian colleagues but like many of the earlier imported solo female dance performers that transformed the Edwardian stage, she focused on pursuing an independent career aided by a complementary company of dancers who served as the vehicle for her promotion. Like Allan, who made extended professional visits to international locations including tours to the United States, South Africa, Australia and India prior to and during the First World War, Pavlova undertook extensive worldwide touring returning only occasionally to Europe. Like Allan, she also visited Hollywood, where she was convinced to dance in the Dumb Girl of Porcini (1916). She purchased a large house with gardens in Hampstead, North London in the early 1920s which became her home after the Russian Revolution. Allan also remained in London until 1941 (CHERNIAVSKY, 1991).

In considering her contribution to dance, Pavlova could be seen to be conservative and canny in the roles that she performed and created for herself. She featured an established repertoire of ballet works that largely came out of the Imperial Russian tradition. These became audience favorites and, not unlike Allan, Pavlova continued this populist approach instead of pursuing the more high art avant-garde attitude that her fellow Russian Diaghilev was simultaneously making famous. The career she built showed an understanding of how to manipulate and stage her performances, for instance arranging the Palace Theatre as the venue for her London debut in 1910 , the same theatre that was associated with the huge success of Allan. And as noted earlier, Pavlova altered her Palace programmes so as to attract the

10 "The Palace: Mdlle. Pavlova," Daily Telegraph, 19 April 1910, The Telegraph Historical Archive; "World's Greatest Dancer: Pavlova in London," Daily Mail, 19 April 1910, UKpressonline; "Art, Music and the Drama," Illustrated London News, 23 April 1910; "Anna Pavlova," The Sketch Supplement, 20 April 1910; "The World's Greatest Dancer," The Tatler, 6 April 1910; and "To Dance in England Again Before Long," The Sketch Supplement, 6 April 1910. same kind of popularity that Allan's dancing enjoyed. Attached to and bolstering her box office successes was a masterful crafting of her public persona which relied on titillating rumors supported by absolute silence about the aspects of her private life (MONEY, 1982). For instance, from early on in her career, Pavlova had an ambiguous relationship with Victor Dandre, a White Russian and former member of the Duma. His role has never really been determined but he was variously postulated to be her manager, a father figure or her husband (PRITCHARD, 2013). This kept audiences and the public guessing and reinforced her public image. This scrupulous suppression of personal details, as in Allan's case, may have been about hiding potentially damaging information. For instance, Pavlova was rumored to have been both illegitimate and Jewish (KERENSKY, 1982) and while this was certainly not as explosive as having a murderous brother, both categories could lead to social stigma. And as we shall see from Allan's example in the late-war period this could carry heavy punishments.

Like Allan, Pavlova had a signature work that she performed throughout her career and came to be firmly associated with her public persona and celebrity. Called The Swan or Le Cygne, or more popularly, The Dying Swan ${ }^{11}$, the work is short piece of only three minutes to the music of Camille Saint-Saëns. It was created sometime between 1905 and 1907 in St Petersburg by the then up-and-coming Russian choreographer Michel Fokine with Pavlova as his dancer (KERENSKY, 1982) and, like Allan's well-known piece, has morbid overtones, depicting the final moment in the life of a swan. What is different from Allan's example is that footage of Pavlova dancing The Dying Swan still exists and the work has had many interpreters after Pavlova, serving as a kind of ultimate measure of ballerina legitimacy. The prominent and innovative aspect of the short work is that it is performed almost entirely using the bourréestep, where the dancer propels herself across the stage space en pointe with a succession of tiny steps, the body

11 I use Dying Swanto refer to the workthroughout. 
held completely still, as if floating across a calm pool of water. It also features choreographed arm movements, or ports de bras, in which arms are made to imitate the seamless sequential movement of a bird's wings as it flies. In The Dying Swan, a singular figure in full tutu and en pointe enters and almost languidly bourréesacross the back with sinuous winged arm movements. This is followed by moments of stillness where she poses as if tormented. She increasingly succumbs to gravity as if fainting, and seems to rally only to admit the inevitable, as she sinks finally and irrevocably to the floor. The whole effect is strikingly zoomorphic and anthropomorphic as the dancing figure seems to shift back and forth between a woman dancing and the swan she is performing.

\section{Figure 3 - Anna Pavlova as the Dying Swan.}

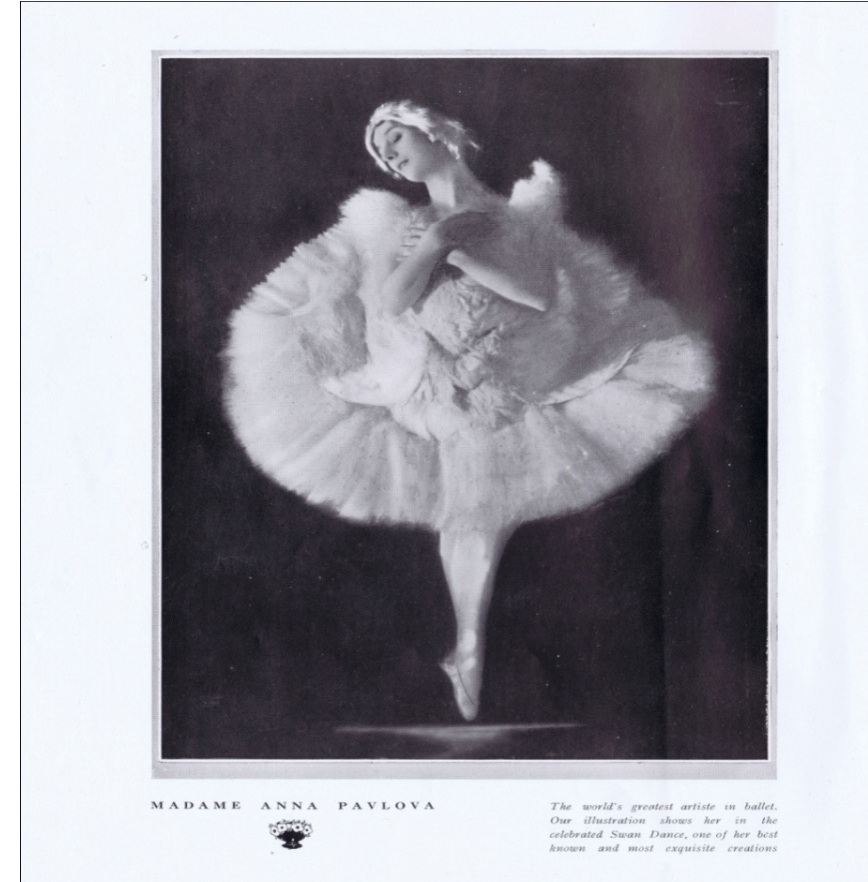

Source: (C) Mary Evans / Jazz Age Club Collection. All Rights Reserved.

Thus while there are some significant points of departure, there are also some striking similarities between these two women within the context of the prewar London cultural milieu that both were introduced into. The next section moves more specifically to considering how their diverging careers after the First World War offer a means to understand the conse- quences of the rapidly shifting ideas about masculinity and femininity in the early twentieth century. I do this with specific reference to two events: Allan's libel case of 1918 and Pavlova's death in 1931. These events will illustrate how Allan and Pavlova's bifurcating histories can be understood to modulate attitudes in the post First World War era, behaviours that included public expressions of anger and fear associated with moral panic and xenophobia as well as grief and sadness linked to mass mourning. Ultimately, I suggest this was about the way these women's dancing came to mean different things about the ways women should be understood for the functioning of a 'healthy' social order.

\section{Iniquity, sacrifice, reintegration}

During the late months of 1917, Allan returned to undertake a London season after an absence of several years. This was not the sparkling belle époque London of the pre-war. The homefrontwas depressed with shortages of household necessities and the heavy emotional burden of catastrophic loss of life. The appalling losses of the Battle of Passchendaele were followed in the new year by rumors of a colossal German offensive planned for the spring (KETTLE, 1977). The fortunes of her close friends the Asquiths were also in decline. Surprisingly Allan's performances were well attended and she was still getting good reviews from her critics ${ }^{12}$. She was in discussions with the London Royal Court Theatre who was arranging to produce a version of Oscar Wilde's play Salome. Public performances of the play were still banned by the Lord Chamberlain's office so the event was to be a private event. In it, Allan was to perform her famous The Vision of Salome as well as take on some speaking parts in the hopes that this would lead to a cross-over career in acting. As was convention with private events, a listing was placed in the classified advertisements section of The Times soliciting interest. In response to the notice, a small, far right newspaper called The Vigilante run by Noel Pemberton Billing published this short provocative notice.

12 Maud Allan's Return, The Tatler, 14 November 1917. 


\section{The Cult of the Clitoris}

To be a member of Maud Allen's performances in Oscar Wilde's Salome one has to apply to Miss Valetta, of 9, Duke Street... If Scotland Yard were to seize the list of these members I have no doubt they would secure the names of several thousand of the first 47,000 (MEDD, 2012, p. 28).

The 47,000 refers to a list identified in an earlier piece in The Vigilante, written by Billing, as a group of men and women in British society who were susceptible to blackmail by German agents due to their hidden sexual perversions. Allan, seeing the article, was provoked to sue for libel, arguing that the "cult of the clitoris" was slandering her by calling her a lesbian. The terms of the lawsuit were published verbatim in The Times with the term 'lesbianism' appearing for the first time in print in England (MEDD, 2012).

Like the Wilde trial almost a quarter of a century before, although Allan initially brought the suit against Billing, it was she who ended up on trial for sexual immorality, as well as, more frighteningly, as a potential enemy of the state. The trial began on May 29th 1918 and ran for six days. Every major British newspaper reported ongoing details of the trial with the Daily Mirror featuring two photographic exposés of the trial over this period ${ }^{13}$.Billing promoted the opinion that Germans were profligate and those that infiltrated Britain as spies spread both venereal disease and homosexuality to undermine the British war effort (MEDD, 2012). His witnesses included Oscar Wilde's former lover, Alfred Lord Douglas and Eileen Villiers-Stuart who claimed to have seen the list which she said also included the judge of the trial, Charles Darling. Billing furthermore claimed thata group of women in upper London so-

1340 See "P.B. Libel Charge," Daily Mirror, 31 May 1918, UKpressonline; "Scenes at Billing Trial," Sunday Times, 2 June 1981, Sunday Times Digital Archive; "The Billing Trial," Daily Mail, 5 June 1918, UKpressonline; "Mr. Billing Acquitted," The Manchester Guardian, 5 June 1918, ProQuest Historical Newspapers; "Acquittal of Mr. Billing," The Times, 5 June 1918; "Pemberton Billing Trial," Daily Telegraph, 5 June 1918, The Telegraph Historical Archive; and "The Defendant cheered by the crowd," Daily Mirror, 5 June 1918, UKpressonline. ciety were practicing homosexuals who sold secrets to the Germans. Fueled by the deprivation of what seemed an endless war and the anxiety over a continued successful German offensive in France (KETTLE, 1977), the trial produced a frenzy which was fed by salacious gossip about Allan's earlier relationship with Margot Asquith, whose nadir in the public's opinion also hurt Allan. Allan's connection to her brother was exposed by Billing to show that sexual perversion was directly related to genetics. The court ruled in favour of Billing, who received great appreciation both inside the packed courtroom and on the packed streets outside. It effectively ended Allan's career and the career of anyone associated with her.

In the public moral frenzy that characterised the Billing Trial, we can witness what Shoshana Felman defines in her co-authored groundbreaking exploration of trauma testimony, as "the state of being stricken, wounded by reality" (FELMAN, 1992, p. 28).Applied to the late-war British populous, what stands in sharp relief is how the event articulated this wounding and illustrated a historical moment where a culture may have been understood to be unravelling. Reassuring norms and beliefs about identity are suddenly and aggressively called into question and bring on particular indicators of trauma including fear, violence, withdrawal, and apprehension. Furthermore, as I have argued elsewhere (THOMS, 2013), the wound to reality that provokes trauma is a complex web of effects involving multiple actors who themselves are both singularly afflicted but also collectively joined. One cannot act without some sort of influence on the other, however unknown or unclaimed. To cite Cathy Caruth, history, like trauma, is "never one's own [...] history is the way we are all implicated in each other's traumas" (CARUTH, 1996, p. 24). The effects of trauma arise not simply in the experiencing of a materially catastrophic event, although the specificity and impact of this singular experience cannot be underestimated; it is the way in which the event sits within a historical context that is enmeshed within socio-cultural value and meaning that informs the psychic injury and its 
palliation. Indeed, the event itself might not be traumatic to begin with but becomes traumatic in the way that it is addressed by social actors and institutions.

Thus the Billing Trial provided an expedient vehicle for the coalescing and articulating of traumata associated with a host of cultural change both directly and indirectly influenced by the war. The trench warfare on the continent was entering its fourth year with increasing social confusion and unrest at home (KENT, 2009).The question of Irish independence and with it concerns about the integrity of the Empire had just come to a head with the violent eruption of the Easter Rising in 1916. The growth of the Labour Party also challenged the traditional status quo, giving a political voice to working class populations, especially with the Representation of the People Act in February of 1918 which granted limited suffrage to women for the first time in British history and enfranchised all men above the age of 21. Indeed, this last example brings into sharp focus the increasingly challenging role gender played in understanding the bounds of social reality. These rapid changes as well as the hysteria of the London home front in the spring of 1918 helped to set the scene for what became a trial about the very character of female identity. Here the question of 'woman' came to articulate the grounds on which the trauma of disintegrating belief systems and knowable identities was negotiated and it is telling that the trial and execution by firing squad of Mata Hari on false charges of espionage took place only six months before the trial ${ }^{14}$.

Central then to Allan's example is an anxiety about her identity as knowable and containable; writ large is the anxiety regarding the inability to tell the difference between friend and enemy that was adeptly played out in Billing's contentions about the hidden connections between sexual perversion, genetics, and treason. Medd brilliantly argues (MEDD, 2012)the libel trial offered a surrogate for the unknow-

14 Mata Hari was executed on 17 October 1917. See Wheelwright (1992), The Fatal Lover, who perceptively writes that "Mata Hari brought together fears about the enemy alien, the wayward woman and sexual decadence." ability of war, demonstrated in the unknowability of lesbian identity. I take a slightly expanded view and suggest that it is not simply how a cultural moment is destabilized by the emergence of lesbian identity but how the emergence of lesbian identity provokes an ontological abyss qua identity full stop. The Billing Trial magnified the impossibility of fully gasping the traumatic magnitude of war by providing an event that threw into question the very relationship between gender and sex, culture and biology, and following Judith Butler (1990), dissolved the taken for granted understanding that identity equals reality. We should be able to tell the difference between men and women and when we cannot it calls into question the very fabric of our existence. We think we know what 'woman' is but all of a sudden women seem to behave a lot like men and simultaneously we think we know 'men' but because of the events of the Great War, the identity of men, as Joanne Bourke (1996) persuasively argues, is also significantly altered.

In highlighting the potential social crisis instituted around the categories of masculinity and femininity, the Billing Trial highlights how gender is a formidable constellation of trauma. By constellation of trauma, I mean a group of interrelated traumas and their effects (fear, anger, withdrawal, psychosis) that operate in relation to gender identity. "Gender is traumatic and trauma is gendered" as Tiffany Joseph reminds us (JOSEPH, 2003, p. 67). On trial was precisely the pre-war figure of the solo dancing woman that Allan's example encapsulated. This figure was a stand in for and coalesced the overwhelming wound to reality caused by the Great War era. Her unrestrained weighted dancing came to demarcate the traumatic boundaries of identity. The trial made publically manifest the very raw and deeply troubling emotions about the war through a questioning of what constituted the proper identity and role for women. In doing so Allan's punishment was assured as she and by association her dancing became untenable for the social order. She became the casualty of this still open wound.

If Allan and her dancing of Salome were the catalyst for articulating the ongoing deep anxiety 
about female identity and the role of femininity for the integrity of the nation, Pavlova's death thirteen years later might be understood to palliate the rip in the body politic by repatriating knowable gendered identities. Her passing on 23rd January 1931 in The Hague was widely reported in the British press ${ }^{15}$ and like the Billing Trial ignited mass public interest. This time, though, united in expressions of grief. The circumstances surrounding her death were no small motivation for the perceived tragedy of her death which presented her last days as the image of a gracious, dedicated, brave and above all self-sacrificing woman. As noted earlier, Pavlova was prolific in her touring and through it she enjoyed a huge international following of ardent and critical admirers. By the end of the 1920s, her zeal for promoting dance meant that she had visited every continent, performing in places like Egypt, South Africa, India, Sri Lanka, Japan, Venezuela, Peru, New Zealand, Australia, Canada and the United States, with weeks long seasons in New York. Yet by the end of 1920s the world economy was also in deep crisis, precipitating even more far flung touring. By this time, Pavlova was in her late 40 s suffering from a constant state of exhaustion and a persistent knee problem. Returning to Europe in the spring of 1930, she continued to tour through the autumn and was undertaking a tour of

15 The Daily Express featured the news of Pavlova's death on their front page. See "Pavlova Dead," Daily Express, 23 January 1931, UKpressonline. The Manchester Guardian reported that same day. See "Death of Mme Pavlova: IIIness during Tour of Holland," The Manchester Guardian, 23 January 1931, ProQuest Historical Newspapers. The Manchester Guardian followed this the next day with "Our London Correspondence: Pavlova as a Friend," The Manchester Guardian, 24 January 1931, ProQuest Historical Newspapers. See also "Pavlova Dead," Daily Express, 23 January 1931, UK pressonline; G.B. "Pavlova Lies in State," Daily Express, 29 January 1931, UK pressonline; and "Personalities of the Week," Illustrated London News, 31 January, 180. Eulogies and memorials reported on by the press extended into the spring of 1931. See as an example, "Pavlova Memoria - Special Performance at the Hippodrome," The Times, 16 Feb 1931, Times Digital Archive; "Anna Pavlova: Some Memories,"Dancing Times, March 1931, 683-692; "The Royal Academy, 1931: A Memory of a Great Dancer," Illustrated London News, 9 May 1931. northern Europe in the New Year. Travelling in early January, Pavlova's train derailed in the night and a piece of luggage hit her in the chest while she was in her sleeping birth. Several sources also reported that she helped to detrain other injured survivors with little concern for her own wellbeing. This was followed by a delay of half a day waiting outdoors and in unheated train compartments. She was already showing signs of significant illness on the subsequent train journey to The Hague were the tour was to begin. This illness was diagnosed days later as pleurisy which continued to worsen. Pavlova purportedly refused to undergo an operation to relieve the pressure on her lungs because it threatened to end her dancing career. She died in the early evening of 22nd January 1931, and it was reported that her last words were for her Swan dress to be made ready (MONEY, 1982).

In thinking about the dynamics of traumatic effect, Pavlova's death offers several registers of insight. Certainly, as I will explore in a moment, it is a collective working through of cultural anxieties via public mourning that valorise traditional femininity. First though as an important corollary, the issue of trauma and temporality bears considering. The complexity of traumatic effect is that it is not fully available, emerging in unsettling phenomena undergone by the sufferers as a delayed response to the experience. Traumatic time is not perceived as the coherent flow of events that characterises normal social reality but rather as a palimpsest of competing temporalities with confused states of consciousness. It is experienced as an overwhelming ubiquitous now. This lack of the sense of passing time also influences the temporal lag associated with the after-effects of trauma. Ann Douglass and Thomas Vogler (2013)for instance use the twenty-year progression of eventual public recognition of and engagement with the Holocaust to illustrate this effect. Traumatic time then can also provide a different understanding of historical eras and their ongoing effects. While proceedings associated with Pavlova's death in 1931 might plainly be attached to the second half of the interwar period, the capacious temporality of traumatic effect connect 
it to the influences of an earlier socio-historic era. It may well bear reiterating that the First World War was an occurrence that, at the time, went beyond the borders of the human imagination and its manifold influences in later events cannot be underestimated. Its traumatic resonances reverberated through, if not beyond, the first half of the twentieth century.

In the context of this delayed response, reactions to Pavlova's death also chime with Susan Kent's thinking on societal symptoms of trauma. Kent explores the British post-war and inter-war psyche and its influence on the politics of the era. She suggests that 'shell shock' theorised as a consequence of the Great War was felt collectively and was articulated in numerous testimonials by both combatants and civilians who felt that they had been "torn to pieces, fragmented their existence, utterly disrupted the flow of what should have been their natural lives" (KENT, 2009, p. 3). The desire to feel whole again and heal the national psyche led to the widespread appeal of conservative politics intent on closely defining and policing the boundaries of the 'English' self from what was perceived as pernicious and invasive others, this including various religious organisations, women, and racial and ethnic groups. If Allan's trial articulated fears about a profound confusion about boundaries of female identity, Pavlova's death more than a decade later might be understood to have helped to re-establish these boundaries. Pavlova's careful progressive cultivation of image made her the epitome of purity, modesty and dedication wrapped in an aura of grace and handsomeness. The circumstances of her death reinforced this image most emphatically. Her sacrifice was not simply to give up everything for her art but to also die for it. Her identity is worthy of mourning, and the mourning is more profound because of worthiness of her identity. She was not only the interpreter par excellence of this submissive grace and surrender but its literal embodiment. Her death provided an event that returned to and asserted a category of femininity that was reassuring and quantifiable. It recoupled gender and sex and offered a remedy for psychosis. Where melancholia, theorised by Sigmund Freud in 1917, is characterised by an inability to identify the specific nature of loss as well as feelings of worthlessness, mourning is a process of acknowledging loss and of social reintegration. Set against a worsening global financial crisis and increased socio-political instability accompanying Hitler's rise to power in Germany - all haunting consequences of the failure of post First World War reconciliation - mourning for Pavlova offered the comfort of celebrating knowable, laudable and containable ideas about women founded on traditional understandings of femininity.

The Dying Swan can be seen to play a central role in the building valorisation of traditional femininity as a social sedative, a claim that becomes more durable if one charts The Dying Swan's journey of influence from its premiere in London before the war, through the 1920s and into the 1930s after Pavlova's death. What is noticeable is that Pavlova's professional persona changes so that by the mid-1920s London, she has fully adopted what Jennifer Fisher has termed "the Swan Brand" (FISHER, 2012, p. 51). Nevertheless, while she danced The Dying Swan at her first pre-War programmes at the Palace in 1910, it was the exuberant and sensual partnered dances with Mikhail Mordkin that her management encouraged and the press reported, featuring the joyous unrestrained character of Greek natural dancing. This can be witnessed in pieces like their Bacchanalewhich was featured in promotion material and press coverage with a titillating medium head shot of Pavlova holding a bunch of grapes close to her mouth and looking over her shoulder in saucy invitation ${ }^{16}$. After the autumn of 1914, Pavlova only returned to London post-war in 1920, this time seemingly eschewing the Palace where she and her company had all of her pre-War London seasons and appearing instead at notable West End theatres such as Drury Lane and Covent Garden. For someone whose choice to perform specifically at the Palace for her London premiere in 1910 was informed by its as-

16 Title page to The Sketch Supplement, 20 April 1910. 
sociation with Allan, this change seems telling. This 1920 return was also reported in several newspapers with specific reference to the world-renowned Swan dance which they reported as being more beautiful than ever after a four-year absence ${ }^{17}$. In 1925 , illustrating the further widening of the social reach and impact of the Swan emblem, the hotelier Gordon Selfridge featured a window showing a replica of Pavlova on stage in a classic pose from The Swan. An image of this was featured in the society periodical The Sketch ${ }^{18}$. This link also illustrates how Pavlova's image synchronized the 1920s commerce which offered the new and exotic - more romantic than erotic - in safe and controlled spaces (DENNIS, 2008).

Nevertheless, the most profound link between Pavlova and the Swan comes with her death. These include obituary notices which featured: reports of Pavlova making "swan" movements just before she died $^{19}$; images of her embracing a swan ${ }^{20}$; "letters to the editor" refining on points made in her earlier published obituary to include "such miracles of interpretation as the Swan"21; and photo essays highlighting The Swan as her signature work ${ }^{22}$. These reports of her death all reinforce the ubiquitous iconic image of her as the dying Swan. Perversely, as a foil for the 'ravenous prurience' of the character of Salome, The Dying Swan came to advocate that death itself is a positive characteristic of hegemonic femininity. In fact, Pavlova's role as the Dying Swan increasingly made her personal story always already a story

17 Pavlova's return' Enthusiastic Welcome at Drury Lane, The Times, 13 April 1920, Times Digital Archive; "London Theatres. Drury Lane. Return of Pavlova," The Stage, 15 April 1920.

18 Commerce pays a tribute to the great art of Mme. Pavlova, The Sketch, 4 November 1925.

19 Obituary - Anna Pavlova, The Stage, 29 Jan. 1931.

20 Personalities of the Week, Illustrated London News, 31 January 1931.

21 Points from Letters, The Times, 26 Jan 1931, Times Digital Archive.

22 Anna Pavlova: Famous Dancer's Covent Garden Triumphs, The Times, 24 Jan. 1931, Times Digital Archive. about death and the healing tragedy of this death.

Pavlova as Dying Swan thus seems to serve as a powerful cypher for obliterating the feminine transgressions celebrated in the Salomania of the Pre-War and transforms into the tragic figure of the Swan who palliates the incontrollable fears associated with modern femininity. The social power of the Swan trope is further revealed by considering how both women have been written into history. It is perhaps telling that Pavlova's memory and her influence has experienced sustained cult status. Much of the work concerning Pavlova is hagiographic and intended for visual as much as textual impact (MONEY, 1982; GLASSTONE, 1984; PRITCHARD, 2013; KERENSKY, 1982; CASEY, 2013; FISHER, 2012) ${ }^{23}$. There is little discussion about the critical impact Pavlova's dancing and celebrity had on different social formations of the last 100 years. To be sure, I am provoked to read this shortage as an effect of those public figures we cannot or will not critically assess for fear of undermining a fragile enabling fantasy about plenitude and wholeness. 'Pavlova' as idea offers a social analgesic, providing sustaining hegemonic fantasies about the ideal woman as beautiful, sacrificing, proper, and of course, heterosexual.

On the other hand, up until the late 1970s Allan had all but disappeared from cultural memory (MCDEARMON, 1978). She was rescued from obscurity in the last decades by sustained interest in her in the areas of Gender Studies, Women's Studies and Cultural Studies, where her example has offered space for the needed cultural excavations (FARFAN, 2015; BLAND, 2013; MEDD, 2012; WALKOWITZ, 2003; KORITZ, 1995; HOARE, 1997; KETTLE, 1977). I have argued throughout that Allan and Pavlova's example offers a way of understanding how gender was a constellation of trauma for the Great War era and maybe this contention is most forcefully illustrated

23 Money (1982), Anna Pavlova; Glasstone (1984), Book Reviews, www.euppublishing.com/doi/pdfplus/10.2307/1290781; Pritchard (2013), Anna Pavlova; and Kerensky (1982), "Review" Notable exceptions that have considered the cultural impact of Pavlova include Casey (2013), Pavlova, and Fisher (2012), "The Swan Brand." 
in how Allan's memory disappeared in such a significant way. In her acclaimed book on the complexity of memory, Susan Rubin Suleiman (2012) suggests that the past is remembered in how a culture understands itself and how it desires to be understood by others. In the pre-war years Allan and Pavlova were both promising dancers with a career ahead of them, linked not only through the theatre they both premiered at but also in perpetuating the (female) freedom associated with natural dancing. Is the traumatic effect of the Great War then also that we are left remembering and celebrating the depiction of the final moments of a beautiful but doomed swan instead of the depiction of female autonomy and self-assurance coalesced in figure of the Salome dancer?

\section{References}

BLAND, L. Modern women on trial: Sexual transgression in the age of the flapper. Oxford and New York: Oxford University Press, 2013.

BOURKE, J. Dismembering the Male: Men's bodies, Britain and the Great War. London: Reaktion Books, 1996.

BUTLER, J. Gender Trouble: Feminism and the Subversion of Identity. New York: Routledge, 1990.

CASEY, C. G. "Pavlova and her Daughters: Genealogies of Contingent Autonomy".In: BALES, M.; ELIOT, K. (Eds.).Dance On its Own Terms: Histories and Methodologies. p. 207-228. Oxford and London: Oxford University Press, 2013.

CARUTH, C. Unclaimed Experience: Trauma, Narrative, History. Baltimore and London: Johns Hopkins University Press, 1996.

CHERNIAVSKY, F. The Salome Dancer: The life and times of Maud Allan. Toronto: McClelland and Stewart Inc., 1991.
DENNIS, R. Cities of Modernity: Representations and Production of Metropolitan Space 1840-1930. Cambridge: Cambridge University Press, 2008.

DOUGLASS, A.; VOGLER, T. Introduction.In: DOUGLASS, A.; VOGLER, T. (Eds.). Witness and Memory: The Discourse of Trauma. p. 9-13.New York and London: Routledge,2003.

FARFAN, P. Masculine Women and Effeminate Men: Gender and Sexuality on the Modernist Stage. British Theatre and Performance 1900-1950. Ed. R. D'Monte. London: Bloomsbury, p. 213-222, 2015.

FELMAN, S; LAUB, D. Testimony: Crises of Witnessing in Literature, Psychoanalysis and History. New York: Routledge, 1992.

FENSHAM, R. Nature, Force, Variation.In:CARTER, A.; FENSHAM, R. (Eds.).Dancing Naturally: Nature, Neo-classicism and Modernity in Early Twentieth-Century Dance.p. 1-15. Basingstoke and New York: Palgrave Macmillan, 2011.

FISHER, J. The Swan Brand: Reframing the Legacy of Anna Pavlova. Dance Research Journal,v.11, n. 1, p. 51-67, 2012.

GLASSTONE, R. Book Reviews: Keith Money, Anna Pavlova: Her Life and Art. Dance Research, v. 2, n. 1, p. 68-73, 1984.

GOEBEL, S; WHITE, J. London and the First World War. The London Journal, v.41, n. 3, p. 199-218, 2016.

HOARE, P. Wilde's Last Stand: Decadence, conspiracy and the First World War. London: Duckworth, 1997.

JOSEPH, T. Non-Combatant's Shell-Shock: Trauma and Gender in F. Scott Fitzgerald's Tender Is the Night. Feminist Formations, v. 15, n.3, p. 64-81, 2003. 
KELLY, K. E. Seeing Through Spectacles: The Woman Suffrage Movement and London Newspapers, 1906 - 13. European Journal of Women's Studies, v. 11, n. 3, p. 327-353, 2004.

KENT, S. K. Aftershocks: Politics and Trauma in Britain, 1918-1931. Basingstoke: PalgraveMacmillan, 2009.

KERENSKY, O. Review: Searching for a Legend. Dance Chronicle, v. 6, n. 1, p. 79-83, 1982.

KETTLE, M. Salome's Last Veil: The libel case of the century. London: Hart-Davis MacGibbon, 1977.

KORITZ, A. Gendering Bodies/Performing Art: Dance and Literature in early Twentieth Century British Culture. Ann Arbor: University of Michigan Press, 1995.

MEDD, J. Lesbian Scandal and the Culture of Modernism. Cambridge and New York: Cambridge University Press, 2012.

MCDEARMON, L. Maud Allan: The public record. Dance Chronicle, v. 2, n.2, p. 85-105, 1978.

MONEY, K. Anna Pavlova: Her Life and Art. London: Harper Collins, 1982.

OVERY, R. The Morbid Age: Britain and the Crisis of Civilization, 1919-1939. London: Penguin, 2009.

PATTERSON, A. Maud Allan, the cult of the clitoris and the future of Britain. In:DEAREY, M.; NICOLÁS, S.; DAVIS, R. (Eds.). Re-visiting Female Evil: Power, Purity and Desire. Boston: Brill-Rodopi, p. 2-10, 2017.

PRITCHARD, J. Anna Pavlova: Twentieth Century Ballerina. London: Booth-Clibborn Editions, 2013.

SULEIMAN, S. R. Crises of Memory and the Second World War. London: Harvard University Press, 2012.
SYMONS, M. The Confection of a Nation: The social invention and social construction of the Pavlova. Social Semiotics, v. 20, n. 2, p. 197-217, 2010.

THOMS, V. Martha Graham: Gender and the Haunting of a Dance Pioneer. Bristol and Chicago: Intellect, 2013.

WALKOWITZ, J. R. The Vision of Salome: Cosmopolitanism and Erotic Dancing in Central London, 1908-1918. The American Historical Review, v. 108, n. 2, p. 337-376, 2003.

WEIGARD, E. The Rugmaker's Daughter, Maud AIlan's 1915 silent film. Dance Chronicle, v. 9, n. 2, p. 237-25, 1985.

WHEELWRIGHT, J. The Fatal Lover: Mata Hari and the myth of women in espionage.London: Collins and Brown, 1992.

Recebido: $14 / 08 / 2020$

Aceito: $28 / 08 / 2021$

Aprovado para publicação: 18/04/2021

Este é um artigo de acesso aberto distribuído sob os termos de uma Licença Crea- tive Commons Atribuição 4.0 Internacional. Disponívelem: <http://creativecommons.org/licenses/by/4.0>.

This is an open-access article distributed under the terms of the Creative Commons Attribution License 4.0 International. Availableat: <http://creativecommons.org/licenses/by/4.0>.

Ce texte en libre accès est placé sous licence Creative Commons Attribution 4.0 International. Disponible sur:<http://creativecommons.org/licenses/by/4.0>. 